高層建築物の弾性模型の開発

\title{
DEVEROPMENT OF MULTI-DEGREE-OF-FREEDOM AEROELASTIC MODEL OF A HIGH-RISE BUILDING
}

\author{
丸川比佐夫 $* 1$ 片桐純治 $* 2$ 藤井邦雄 $* 3$ 大熊武司 $* 4$
}

Hisao MARUKAWA, Junji KATAGIRI, Kunio FUJII, Takeshi OHKUMA

\section{SUMMARY}

This paper describes new ideas and some improvements in the development of a multi-degree-of freedom aeroelastic model of a high-rise building. With this model, the mass, the eccentric distance, the frequency ratio of a torsional mode vibration to sway mode vibration, and the structural damping can be changed easily. A structural skin which reproduces the exterior geometry is discontinuous with slits separating the various zones of the model. The effect on the wind responses with these slits is in farther investigation.

\section{1.はじめに}

高層建築物の風荷重は建築物の応答を考虑して定め られている. 通常の場合, 設計風速は共振風速以下で あることが多く，振動に伴う風力いわゆる振動依存風 力は無視できる程度に小さい，そのため，多くの規準 あるいは指針では，建築物が静止時に作用する風力を 用いて,建築物の応答が求められるようになっている. 建築物の高層化，軽量化あるいは低減衰の建築物の出 現にともない, 設計風速が共振風速に接近するあるい は越えるようになることが想定される場合には, 振動 依存風力は無視できない，建築物の応答あるいは荷重 は弹性模型によって応答を測定することによって求め
るか，あるいは強制振動法等によって得られた振動依 存風力を考虑して求める [1]ことになる.

建築物の㨭れの固有振動数が並進の固有振動数に比 較して充分大きい場合は, 建築物の自励的振動は風直 角方向に対して生じることより，並進方向の 2 方向に ロッキング振動が再現できるジンバル装置が開発され, 多くの建築物の耐風設計に利用されてきた. しかし, 偏心を有する高層建築物で, かつ並進の固有振動数と 摸れの固有振動数が接近するような高層建築物の出現 に備えて, 並進の振動と挨れの振動が同時に再現でき る模型の開発が早急の課題となってきている. 模型は 相似則に従って作成すればよいわけであるが，比較的

1 (株) 泉創建エンジニアリング 都市環境技術研究所, 副所長

Vice-head, Urban Environment Research Center, Izumi Sohken Engineering Co., Ltd.

2 (株) 風工学研究所, 主任研究員

Chief Research Engineer, Wind Engineering Institute Co., Ltd.

3 (株) 風工学研究所, 所長

President, Wind Engineering Institute Co., Ltd.

4 神奈川大学, 工学部建築学科, 教授

Professor, Department of Architecture and Building Engineering, Kanagawa University 
簡単に满足させることができる相似パラメータとなか なか嚾しいものがある. 本報告は高層建築物を対象と した汎用性の高い多質点弾性模型の開発において工夫 した点および問題点を取り總めたものである.

\section{2. 問題点とその㳔応}

開発した多質点弾性模型の骨組みの写真, 平面図お
よび断面図を図1に示す，以下に相似パラメータ別に 工夫した点および問題点を線める。なお，本模型を用 いて行った研究成果については文献 [2][3][4] 等を参照 して頂きたい。

\section{1 幾何学的相似}

幾何相似を満足するためには個々の建築物に応じて 外郭形状を变える必要がある. 様々な模型形状に適用

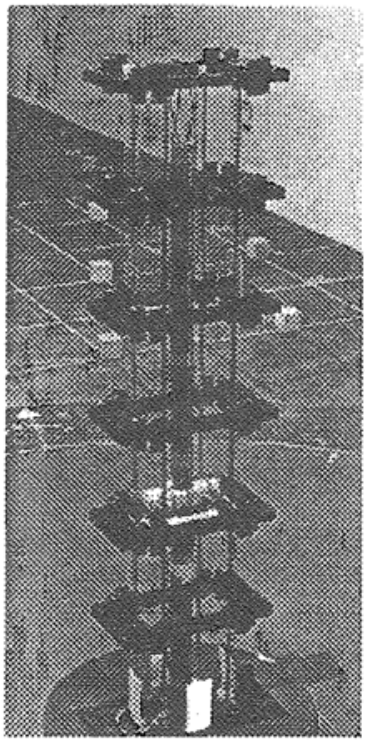

(a) 骨組写蒖

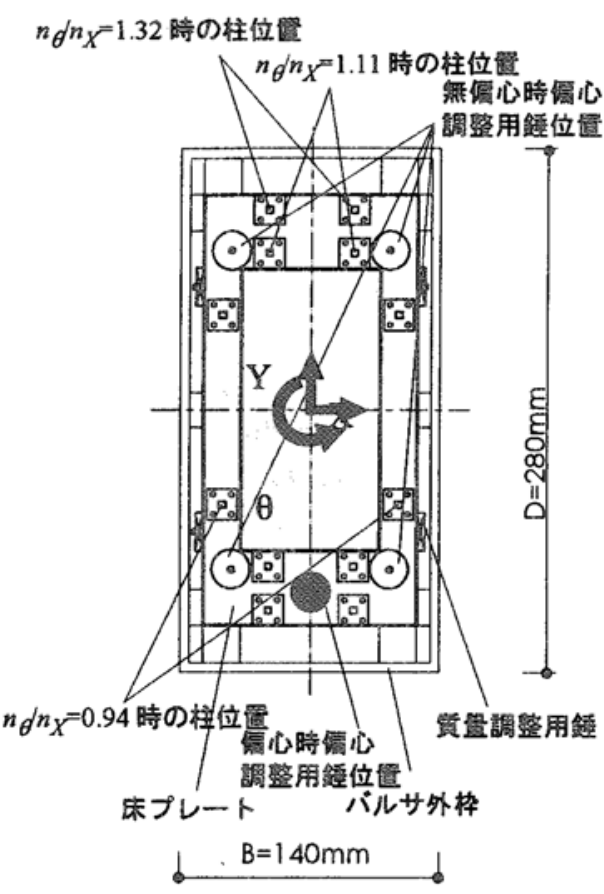

(b) 平面图

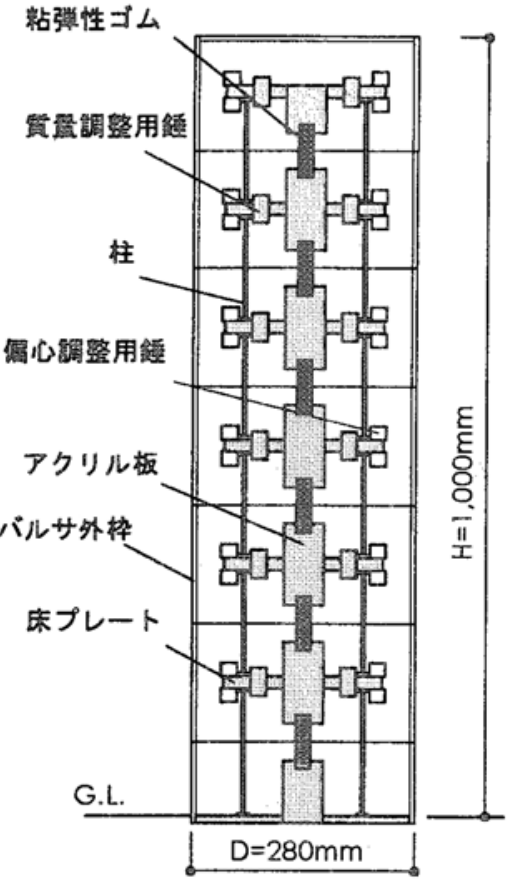

(c) 断面図

图1 多筫点系弹性模型

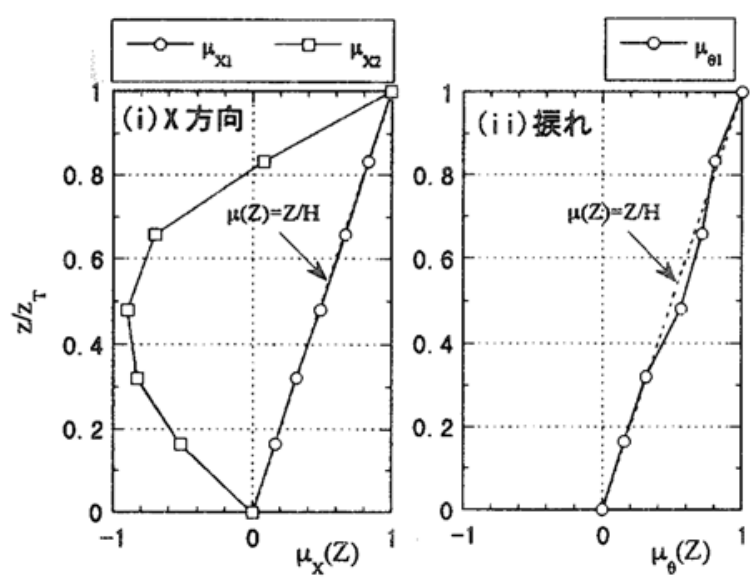

（ヨ）無偏心時

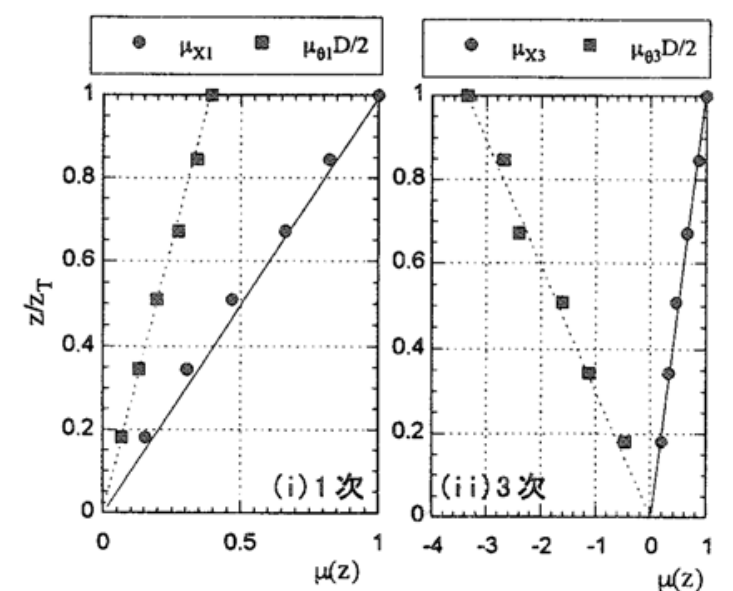

(b) 偏心時 $\left(e_{Y} / j=0.22\right)$

図 2 振辎モード 
可能とするために外郭模型が取り付けやすいことを主 クが接触しない籁囲でできるだけ小さくした（1 $\mathrm{mm}$ 以 眼とした. 模型の犋量分布は後述する調整機能を持た 下). 隙間の問題は今後の課題として残っている.

せることとし，建築物の外郭模型が模型の啠量に占め る割合を小さくするために, $3 \sim 5 \mathrm{~mm}$ のバルサ材を用 いた. 外郭模型は質点の位置で構造体に取り付けられ る.この場合外郭模型のプロック間の隙間については, 斉藤, 本田等[5]が指摘するように応答に影響を与える 可能性があるが，隙間をテープ等で密閉することによ る䐔性, 堿衰への影響, とりわけ堿哀に与える影響が 大きく, 減衰の調整が困難となった. 本模型では, 外 郭模型のブロック間の隙間を応答時に隣接するブロッ

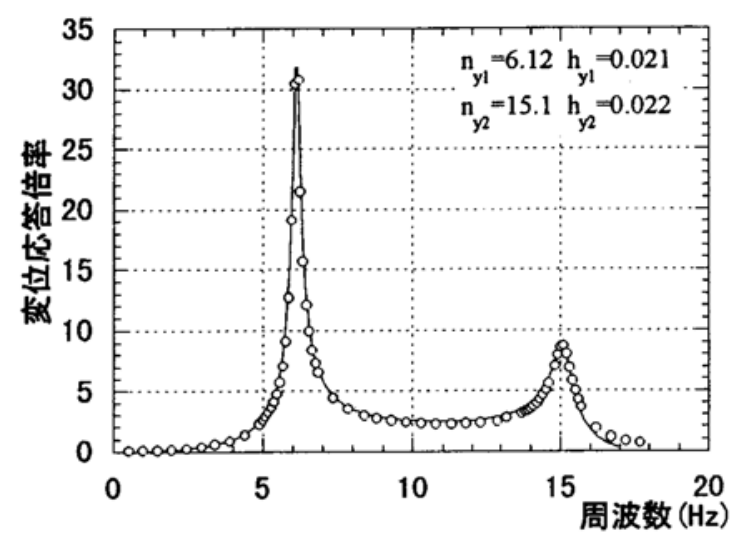

（a）振剑台による測定

\section{2 振動モードの一致}

風応答を対象とした場合, 建築物の振動は各方向の 1 次振動モードの振動が卓越する. 制振装置を設固し た場合においても, 各方向の 2 次振動モードの振動ま で対象とすれば充分である考えられる. 各方向の 2 次 振動モードまで再現するためには模型の質点は 6 質点 で充分である.

建築物の変形は曲げ・せん断型であるが, 通常の建 筑物を対象とした場合せん断型変形が卓越する. 本模

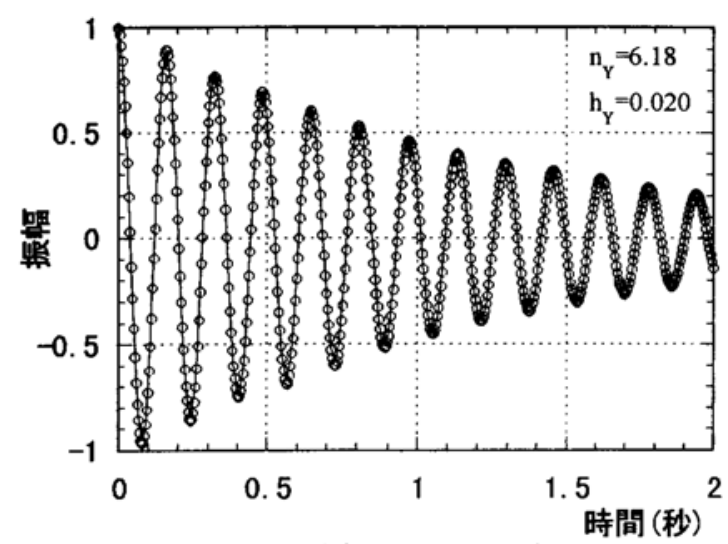

（b）自由振動による測定

图 3 搆造減衰定数の測定例

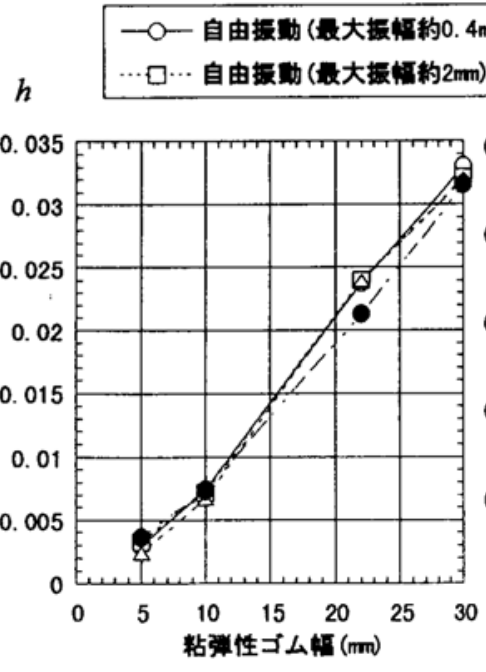

(a) $\mathrm{X}$ 方向

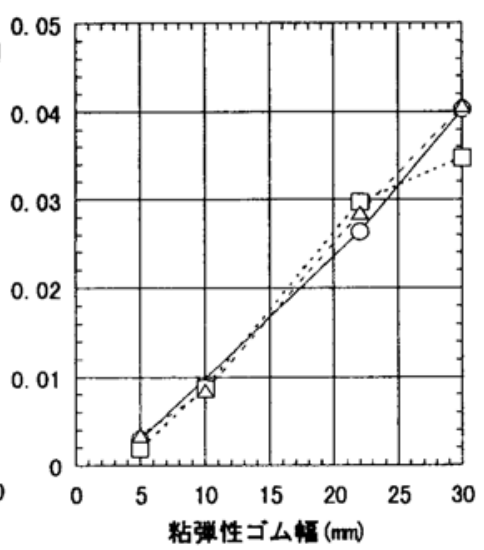

(b) 据れ

図 4 粘弾性ゴムの幅による櫵造隇衰定数の变化

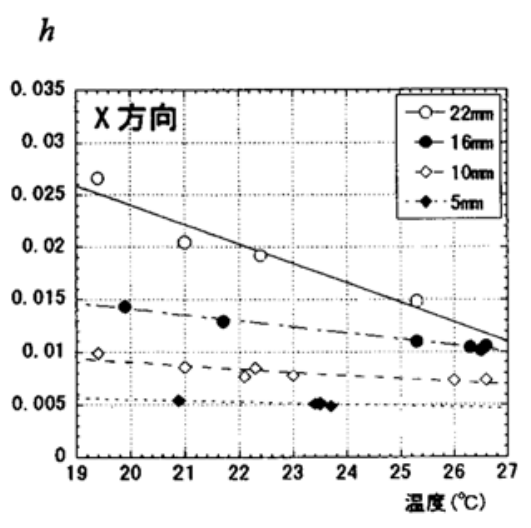

図 5 粘弾性コムによる構造減衰定数 の温度依存性 
型はせん断型変形をするものを対象とし，各方向の 1 次振動モードは直線形で示されるとした(図2). 曲げ 変形が卓越するような構造物については, Isyumov[6] が提案しているモデルの検討が必要となる.

\section{3 質量の眮整}

建築物の場合，高さ方向に質量が一様に分布しない ことが多々ある. また偏心を有する場合もある．これ らのことを考虑して，本模型では質量調整用鍾と偏心 調整用鍾を別に設けることによって質量調整および質 量中心の調整が比較的簡単に行うことができるように してある.この方法によると平面中心に関する慣性 モーメントを変化させることなしに偏心率を変化させ ることも可能である.

\section{4 各方向の振勤数の調整}

柱の柱脚および柱頭にプレートを溶接付けとし, 質 点プレートに 4 点でねじ止めで固定した. 数值計算結 果と比較することによって柱脚および柱頭と質点プ レートの接合は剛接合と見做すことができることを確 認している. 柱断面の形状は矩形とし, 柱断面の辺長 比を変化させることによって並進 2 方向の振動数比を 変化させた. 並進と据れの振動数比は中心からの距離 を変化させることによって調整できる.

\section{5 構造隇衰定数の調整}

応答値は構造减衰定数に大きく依存する. また, 構 造堿衰定数が応答の振幅によって変化することが危惧 される. 本模型では構造減衰定数の調整は質点間に 貼った粘弾性ゴムの幅および貼付位置によって行った. 構造减衰定数は振動台による強制加振によって得られ た共振曲線および自由振動実験から求めた (図 3).

各方向の 1 次振動の構造减衰法粘弹性ゴムの幅にほ ぼ比例して調整できることが明らかになった（図4). 高次の振動の減衰定数の調整には粘弹性ゴムの貼付位 置に工夫する必要がある. 初期振幅を変化させた自由 振動実験によって, 振幅の依存性は層間変形角 $1 / 200$ 以下についてはほとんど無いことを確認している。こ れ以上の大振幅については不明である.

粘弾性ゴムの性質上, 温度依存性が考えられる. 温 度と構造堿衰定数の関係の一例を図 5 に示す. 特に粘 弾性ゴムの幅が大きい時には温度によって構造減衰定 数が大きく変化する. 実験を行う場合は, 頿繁に構造
堿衰定数の確認あるいは調整を行う必要がある.

\section{3. おわりに}

建築物の多様性に伴い今後, 弾性模型による研究あ るいは調查が多くなってくることが予想される．筆者 等は汎用性のあるものを目指して模型の開発を行った が, 全ての問題点が解決したわけではなく, 改良すへ き点が多々あることは承知している.この研究をきっ かけにしてより汎用性のある弾性模型の開発が進むこ とを期待する.

\section{参考文献}

[1] 大能, 丸川, 片桐, 鶴見, 二次元矩形断面構造物に 作用する振動依存風力特性に関する基礶的研究, 日本 建筑学会構造系論文集第 512 号, 1998 年 10 月,pp39-46 [2] 丸川, 片桐, 勝村, 藤井, 多質点系弾性模型の開発 と高層建築物の風応答評価についての検討, 日本建築 学会構造系論文集第 404 号, 1996 年 6 月, pp39-48

[3] 片桐, 丸川, 大熊, 藤井, 高層建築物の風応答にお ける風直角方向と挨れの固有振動数比の影響に関する 研究, 日本建築学会構造系論文集第 507 号, 1998 年 5 月, pp21-27

[4] 片桐, 丸川, 大熊, 勝村, 偏心を有する高居建築物 の風応答性状に関する研究, 日本建築学会構造系論文 集第 514 号, 1998 年 12 月

[5] 斎藤, 本多, 藤本, 渡部, 三次元弾性体模型を用い た風洞試験方法について - 外形材ブロック間の隙間の 影響-, 土木学会第 45 回年次学術講演梗概集, 1990 年 [6] Isyumov,N., The Aeroelastic Modeling of Tall Builfings, International Workshop on Wind Tunnel Modeling for Civil Engineering Applications, Cambridge Univercity Press, 1983, pp373-407 